\title{
EFFECT OF FOLIAR APPLICATION OF BORON AT DIFFERENT STAGES OF CROP GROWTH ON NUTRIENT UTILIZATION AND YIELD OF RICE (Oryza sativa L.)
}

\author{
SANDEEP KUMAR PATEL ${ }^{a}$, R. P. SINGH ${ }^{\mathrm{b} 1}$, SAURABH SHRIVASTAVA ${ }^{\mathrm{c}}$, A. K. PANDEY ${ }^{\mathrm{d}}$ AND S. K. \\ S. CHANDEL ${ }^{\mathrm{e}}$ \\ abcde Department of Agricultural Chemistry and Soil Science, Udai Pratap (Autonomous) College Varanasi, Uttar Pradesh, India
}

\begin{abstract}
A field experiment was conducted during Kharif season of 2016 on research plot of Udai Pratap (Autonomous) College, Varanasi (U.P.) to study the effect of foliar application of boron at different stages of crop growth on rice (Oryza sativa L.). The experimental soil was sandy loam having available nitrogen $144 \mathrm{~kg} \mathrm{ha}^{-1}$, available phosphorus $12.2 \mathrm{~kg} \mathrm{ha}^{-1}$, available potassium 165 $\mathrm{kg} \mathrm{ha}^{-1}$ and available (hot water extractable) boron $0.17 \mathrm{ppm}$. The experiment was carried out in randomized block design (RBD) with six treatments and three replications. Treatments were $\mathrm{T}_{0}=\mathrm{RDF}, \mathrm{T}_{1}=\mathrm{RDF}+\mathrm{B} @ 1.5 \%$ at $\mathrm{TFG}$ stages, $\mathrm{T}_{2}=\mathrm{RDF}+\mathrm{B} @ 1.5 \%$ at TF stages, $\mathrm{T}_{3}=\mathrm{RDF}+\mathrm{B} @ 1.5 \%$ at TG stages, $\mathrm{T}_{4}=\mathrm{RDF}+\mathrm{B} @ \mathbf{2 . 0} \%$ at $\mathrm{T}$ stage, $\mathrm{T}_{5}=\mathrm{RDF}+\mathrm{B} @ 1.5 \%$ at FG stages (RDF=Recommended dose of fertilizers, $T=$ Tillering; $F=$ Flowering; $G=$ Grain filling). Significantly highest grain (42.0 q ha $\left.{ }^{-1}\right)$ and straw (94.87 $\left.\mathrm{q} \mathrm{ha}^{-1}\right)$, yield was recorded with two foliar sprays @ 1.5\% boron at tillering and grain filling stage as compared to control or other treatments. The same treatment also registered maximum nutrient (N, P, K and B) uptake by plant and grain.
\end{abstract}

KEYWORDS: Boron, Foliar Application, Rice, Nutrient Utilization

Boron is, of all the micronutrients, the least understood. Boron is neither an enzyme constituent nor does it affect enzyme activities in the plant. Boron, however, is involved in or plays a major role in a number of plant functions, some of which are not clearly understood, (Cheng and Rerkasem; 1993, Dell and Huang; 1997, Rerkasem and Jamjod; 2004). The key role of boron in plants includes floral organs and flower male fertility, pollen tube growth and utilization of carbohydrates. Therefore, the unavailability of boron during grain setting period results in poor anther and pollen development and the grain thus formed is often without starch. In the field, sexual reproduction is often more affected by low boron and significant grain yield reductions may occur without visual symptoms expressed during vegetative growth. It is believed that B deficiency affects pollen development during the pollen mother cell stage which coincides with the booting stage. Boron has also helped to reduce disease severity in some crops because of the effect that B has on plant metabolism, cell membranes and cell wall structure.

Intensive cropping systems and the use of high yielding hybrids have resulted in depletion of soil micronutrients. Globally, B deficiency has been recognized as the second most important micronutrient constraint in crops. Boron is absorbed by plants as boric acid, which is easily leached in soils. Foliar nutrient sprays may be an effective way to correct boron deficiencies, which some times results in higher yields and crop quality. Advantages of a foliar application compared to a soil application included rapid plant response, increased convenience and effective placement. Foliar sprays of boron is most useful when roots of plants are not able to absorb required amount of boron from soil due to the soil chemical and physical properties such as $\mathrm{pH}$, organic matter, calcium carbonate, soil texture, soil moisture temperature, microbial action and losses from leaching.

Rice (Oryza sativa L.) is the most important food crop of India in term of area, production and consumer preference. India is the second largest producer and consumer of rice in the world. Rice production in India crossed the mark of 111.01 million tonnes (MT) in 2017-18 accounting for $23.3 \%$ of global production in that year. The productivity of rice has $3576 \mathrm{~kg}$ per hectare in $2017-18$. But still very low as compared to other top rice growing countries.

Imbalanced fertilizer application under micronutrient (B) deficient condition is one of the major constraints for attaining higher productivity of rice in sandy loam soil. Keeping above information in view, it is of practical significance to study the role of boron in nutrient utilization and effect on growth and yield of rice.

\section{MATERIALS AND METHODS}

A field experiment was conducted during Kharif season of 2016 on research plot of Udai Pratap 
(Autonomous) College, Varanasi (U.P.) Soil of that particular field was sandy loam, with $\mathrm{pH} 7.67$, organic carbon $0.63 \%$, available nitrogen $144 \mathrm{~kg} \mathrm{ha}^{-1}$, available phosphorus $12.2 \mathrm{~kg} \mathrm{ha}^{-1}$ available potassium $165 \mathrm{~kg} \mathrm{ha}^{-1}$ and available (hot water extractable) boron $0.17 \mathrm{ppm}$. The experiment was laid out in a randomized block design (RBD), with six treatments and three replications. Treatments were $\mathrm{T}_{0}=\mathrm{RDF}, \mathrm{T}_{1}=\mathrm{RDF}+\mathrm{B} @ 1.5 \%$ at $\mathrm{TFG}$ stages, $\mathrm{T}_{2}=\mathrm{RDF}+\mathrm{B} @ 1.5 \%$ at $\mathrm{TF}$ stages, $\mathrm{T}_{3}=\mathrm{RDF}+\mathrm{B} @$ $1.5 \%$ at $\mathrm{TG}$ stages, $\mathrm{T}_{4}=\mathrm{RDF}+\mathrm{B} @ 2.0 \%$ at $\mathrm{T}$ stage, $\mathrm{T}_{5}=$ $\mathrm{RDF}+\mathrm{B} @ 1.5 \%$ at FG stages (RDF=Recommended dose of fertilizers, $\mathrm{T}=$ Tillering; $\mathrm{F}=$ Flowering; $\mathrm{G}=$ Grain filling). Rice (var. Damini) was taken as test crop. Recommended dose of fertilizer $\mathrm{N}: \mathrm{P}_{2} \mathrm{O}_{5}: \mathrm{K}_{2} \mathrm{O}$ were applied @ 120:60:60 kg $\mathrm{ha}^{-1}$ respectively. Half dose of nitrogen and full doses of phosphorus and potassium were applied as basal dressing at the time of transplanting and rest amount of $\mathrm{N}$ was applied in two equal splits, first at tillering and second at ear head initiation stage as top dressing. Boron treatments were applied at different growth stages @ 1.5 and 2\% foliar spray using borax $(11 \% \mathrm{~B})$. Important growth parameters viz; plant height and number of tillers were recorded at various growth stages. Dry matter (grain and straw) yield was determined after harvesting of crop. Plant and grain samples were analysed using standards methods to find out nutrient content.

Soil samples were analysed for determination of organic carbon (Walkley and Black; 1934), available phosphorus (Olsen's et al., 1954), available potassium (Jackson; 1973), available nitrogen (Subbiah and Asija; 1956) and available B by hot water extraction method
(Berger and Troug; 1939). Plant and grain samples were dried at $70^{\circ} \mathrm{C}$ for 12 hours. $0.5 \mathrm{~g}$ ground sample was digested in sulphuric acid and perchloric acid with the ratio of 9:1 and digested samples were used to determine the nitrogen, phosphorus and potassium content. Nitrogen in acid extract was determined by micro Kjeldahl's method, phosphorus colorimetrically and potassium by flame photometer (Jackson; 1973). Dry ashing method, (Chapman and Pratt; 1961) was adopted for the preparation of grain and plant samples to estimate B. One g dry and ground material was taken in porcelain crucible and kept in muffle furnace at $550{ }^{\circ} \mathrm{C}$ for $6 \mathrm{~h}$. Thereafter, ash was wetted into the porcelain crucibles using five drops deionised water and $10 \mathrm{~mL} 0.36 \mathrm{~N} \mathrm{H}_{2} \mathrm{SO}_{4}$ solution was added into it. The content was heated on a steam bath for 20 min then kept at room temperature for $1 \mathrm{~h}$, and filtered through Whatman No. 1 filter paper into a $50 \mathrm{ml}$ polypropylene flask and used for $\mathrm{B}$ analysis. Boron content in the plant digest was determined by spectrophotometer using azomethine- $\mathrm{H}$ (John et al., 1975).

\section{RESULTS}

Boron application brings significant variation in plant height of rice. The height significantly increased as compared to control (no boron). The maximum plant height was recorded in RDF + B @ 1.5\% at TG stages and minimum was noticed in control (RDF) at various stages of crop growth (Table 1). The data (Table 1) also indicated that boron had significant effect on the number of tillers per plant at various stages of plant growth and the highest and lowest numbers were respectively in $\mathrm{T}_{3}$ and $\mathrm{T}_{0}$.

Table 1: Plant Height and Number of Tillers as Affected by Different Treatments

\begin{tabular}{|c|c|c|c|c|c|c|}
\hline \multirow{2}{*}{ Treatment } & \multicolumn{2}{|c|}{ 30 DAT } & \multicolumn{2}{c|}{ 45 DAT } & \multicolumn{2}{c|}{ 60 DAT } \\
\cline { 2 - 7 } & $\begin{array}{c}\text { Plant height } \\
(\mathbf{c m})\end{array}$ & Tillers plant $^{-1}$ & $\begin{array}{c}\text { Plant height } \\
(\mathbf{c m})\end{array}$ & Tillers plant $^{-1}$ & $\begin{array}{c}\text { Plant height }_{(\mathbf{c m})} \\
\mathbf{T}_{\mathbf{0}}\end{array}$ Tillers plant $^{\mathbf{1}}$ \\
\hline $\mathbf{T}_{\mathbf{1}}$ & 70.17 & 4.33 & 82.49 & 5.67 & 101.00 & 5.25 \\
\hline $\mathbf{T}_{\mathbf{2}}$ & 79.50 & 5.17 & 89.24 & 6.70 & 108.22 & 6.50 \\
\hline $\mathbf{T}_{\mathbf{3}}$ & 91.81 & 5.76 & 94.42 & 7.50 & 113.05 & 7.72 \\
\hline $\mathbf{T}_{\mathbf{4}}$ & 82.64 & 6.63 & 97.92 & 7.27 & 125.46 & 8.67 \\
\hline $\mathbf{T}_{\mathbf{5}}$ & 88.09 & 7.30 & 100.99 & 8.25 & 127.61 & 9.41 \\
\hline $\mathbf{S E m} \pm$ & 0.547 & 0.082 & 0.885 & 0.234 & 0.922 & 0.108 \\
\hline $\mathbf{C D}(\mathbf{P}=\mathbf{0 . 0 5})$ & 1.725 & 0.258 & 2.788 & 0.739 & 2.905 & 0.339 \\
\hline
\end{tabular}

DAT $=$ Days after transplanting 
The grain and straw yield significantly increased with foliar application of boron when compared with without boron (Figure 1) being maximum of $42.00 \mathrm{q} \mathrm{ha}^{-1}$ and $94.87 \mathrm{q} \mathrm{ha}^{-1}$ respectively. The corresponding value showed 6.5 and 21.5 per cent increase over control (RDF). The $\mathrm{N}, \mathrm{P}, \mathrm{K}$ and $\mathrm{B}$ contents of rice straw and grain increased significantly over control with foliar application of boron (Table 2). The nitrogen content in straw and grain varied from 0.375 to $0.475 \%$ and 1.50 to $1.97 \%$ respectively. Phosphorus content in straw (0.11 to $0.27 \%)$ and in grain (0.37 to $0.62 \%)$ was observed. In case of potassium, content varied from 0.47 to $0.95 \%$ (straw) and 1.80 to $2.15 \%$ (grain). The maximum contents were recorded with $\mathrm{T}_{3}(\mathrm{RDF}+\mathrm{B} @ 1.5 \%$ at $\mathrm{TG}$ stages $)$. Similar trend was also found in case of nutrients uptake by straw and grain. The total nitrogen uptake varied from 88.40 to $124.86 \mathrm{~kg} \mathrm{ha}^{-1}$, phosphorus from 23.16 to 51.56 and potassium from 115.37 to $180.42 \mathrm{~kg} \mathrm{ha}^{-1}$. The maximum total upake (straw + grain) of $\mathrm{B}$ was $1588.56 \mathrm{~g} \mathrm{ha}^{-1}$ $\left(1243.74+344.82 \mathrm{~g} \mathrm{ha}^{-1}\right)$ registered in $\mathrm{T}_{3}$.

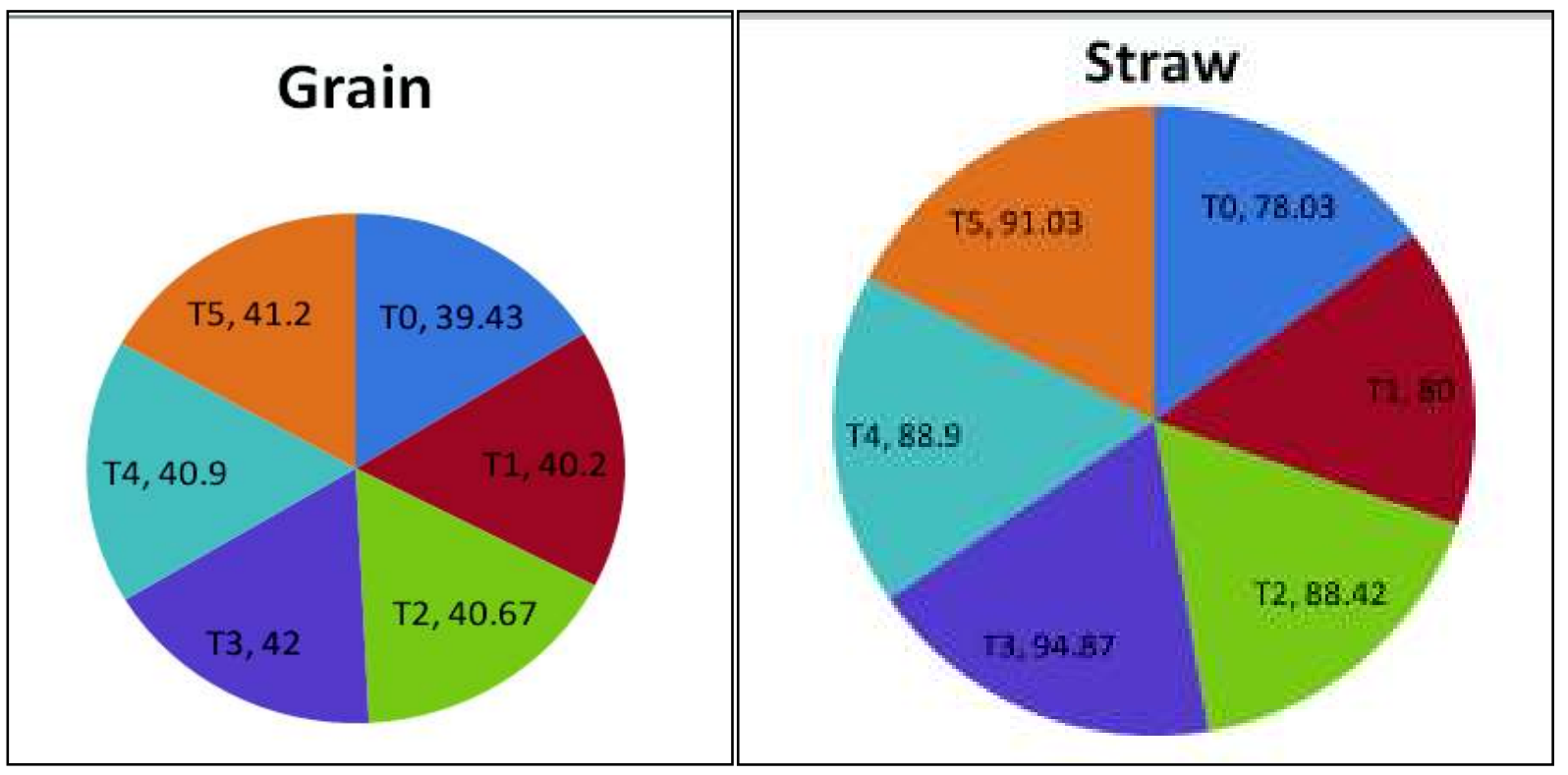

Figure 1: Grain and straw yield $\left(\mathrm{q} \mathrm{ha}^{-1}\right)$ as affected by different treatments

Table 2: N, P, K and B Content in Rice as Affected by Different Treatments

\begin{tabular}{|c|c|c|c|c|c|c|c|c|}
\hline \multirow{2}{*}{ Treatment } & \multicolumn{2}{|c|}{ Nitrogen (\%) } & \multicolumn{2}{c|}{ Phosphorus (\%) } & \multicolumn{2}{c|}{ Potassium (\%) } & \multicolumn{2}{c|}{ Boron (ppm) } \\
\cline { 2 - 9 } & Straw & Grain & Straw & Grain & Straw & Grain & Straw & Grain \\
\hline $\mathbf{T}_{\mathbf{0}}$ & 0.375 & 1.50 & 0.11 & 0.370 & 0.47 & 1.80 & 10.28 & 4.56 \\
\hline $\mathbf{T}_{\mathbf{1}}$ & 0.410 & 1.60 & 0.16 & 0.40 & 0.72 & 1.90 & 10.91 & 5.62 \\
\hline $\mathbf{T}_{\mathbf{2}}$ & 0.430 & 1.67 & 0.19 & 0.47 & 0.80 & 1.96 & 11.47 & 6.41 \\
\hline $\mathbf{T}_{\mathbf{3}}$ & 0.475 & 1.97 & 0.27 & $0 . .62$ & $0 . .95$ & 2.15 & 13.11 & 8.21 \\
\hline $\mathbf{T}_{\mathbf{4}}$ & 0.445 & 1.75 & 0.22 & 0.51 & 0.89 & 2.02 & 12.20 & 6.98 \\
\hline $\mathbf{T}_{\mathbf{5}}$ & 0.450 & 1.84 & 0.25 & 0.57 & $0 . .93$ & 2.11 & 12.81 & 7.58 \\
\hline $\mathbf{S E m} \pm$ & 0.0142 & 0.0146 & 0.0055 & 0.0169 & 0.0068 & 0.0624 & 0.383 & 0.118 \\
\hline $\mathbf{C D}(\mathbf{P}=\mathbf{0 . 0 5})$ & 0.0447 & 0.0438 & 0.0174 & 0.0505 & 0.0214 & 0.1872 & 1.207 & 0.372 \\
\hline
\end{tabular}




\section{PATEL ET. AL.: EFFECT OF FOLIAR APPLICATION OF BORON AT DIFFERENT STAGES OF CROP...}

\section{DISCUSSION}

Results of the present study clearly indicates that application of B (foliar spray) significantly increased the growth parameters viz; plant height and number of tillers (Table 1). Mubshar et al., (2012), El-Dissoky et al., (2013), Rehman et al., (2014) and Abde-Motagally and ElZohri (2016) also reported significant increase in growth parameters in various crops due to application of boron in general and foliar application in particular. In the present study, maximum increase was recorded in case of $T_{3}$. This enhancement in plant growth due to boron application at tillering and booting (grain filling) stage indicates the importance of $\mathrm{B}$ in nitrogen and phosphorus usage by plants at this stage (Ahemad; 2001). Soomro (2011) reported that the maximum number of green leaves was recorded when boron was applied through foliar spray at early mid and late whorl stage in maize. By the foliar application of B plants took up boron readily as compared to soil applied. Tarique et al., (2010) stated that foliarly applied boron could give better results compare to soil applied. Rehman et al., (2014) also observed that foliage applied B improved leaf elongation, tillering and leaf chlorophyll contents.

Significant increase in straw and grain yield (Figure 1) of rice in present study may be due to greater requirement of the nutrient by crop and deficiency of boron in experimental soil. Improvement in grain yield by B application was attributed to increase in grain size and decrease in panicle sterility (Rehman et al., 2014).
According to Jaiswal et al., (2015), the increase in seed yield might be due to the role of B in viability, germination and growth of pollen tubes. In present study, maximum yield was recorded with $\mathrm{T}_{3}$. Rehman et al., (2012) also reported that foliar application of boron in booting stage increases number of grains per spike and thousand grain weight.

It can be seen from the results (Table 3) that the foliage application of boron at different stages of growth significantly improved the nutrients $(\mathrm{N}, \mathrm{P}, \mathrm{K}$ and $\mathrm{B})$ content and their uptake by grain and straw. Similar results were also reported by Singh et al., (2000), Chander et al., (2010), Hossain et al., (2011) and Sentimenla et al., (2012). According to El-Dissoky et al., (2013), nitrogen uptake significantly increased by foliar application of B levels. This effect may be return to role of B in synthesis of amino acids and protein. The increase in phosphorus uptake may be attributed to role of B in root tips, where as membrane bound ATPase activity is influenced by boron levels in the root (Canada; 2002). The effect of B on K- uptake may be related to synergism relationship between $\mathrm{K}$ and $\mathrm{B}$ at sugar and carbohydrate transport (Kar and Motirmani; 1976). Significant increase in B uptake might be due to the influence of foliar application of boron at crucial stages of plant growth. The higher content in straw and grain in turn resulted in higher uptake as well. This is in the similar line as reported by Singh and Goswani (2014) and Jaiswal et al., (2015).

Table 3: N, P, K and B Uptake as Affected by Different Treatments

\begin{tabular}{|c|c|c|c|c|c|c|c|c|c|c|c|c|}
\hline \multirow{2}{*}{ Treatment } & \multicolumn{3}{|c|}{ Nitrogen $\left(\mathbf{~ k g ~ h a}^{-1}\right)$} & \multicolumn{3}{c|}{ Phosphorus $\left(\mathbf{k g ~ h a}^{-1}\right)$} & \multicolumn{3}{c|}{ Potassium $\left(\mathbf{k g ~ h a}^{-1}\right)$} & \multicolumn{3}{c|}{ Boron $^{\left(\mathrm{g} \mathrm{ha}^{-1}\right)}$} \\
\cline { 2 - 14 } & Straw & Grain & Total & Straw & Grain & Total & Straw & Grain & Total & Straw & Grain & Total \\
\hline $\mathbf{T}_{\mathbf{0}}$ & 29.26 & 59.14 & 88.4 & 8.58 & 14.58 & 23.16 & 44.4 & 70.97 & 115.37 & 796.68 & 179.80 & 976.48 \\
\hline $\mathbf{T}_{\mathbf{1}}$ & 32.80 & 64.32 & 97.12 & 12.80 & 16.08 & 28.88 & 57.6 & 76.38 & 133.98 & 872.8 & 225.92 & 1098.72 \\
\hline $\mathbf{T}_{\mathbf{2}}$ & 38.02 & 67.91 & 105.93 & 16.79 & 19.11 & 35.9 & 70.73 & 79.71 & 150.44 & 1014.17 & 260.69 & 1274.86 \\
\hline $\mathbf{T}_{\mathbf{3}}$ & 45.06 & 79.8 & 124.86 & 25.61 & 26.04 & 51.65 & 90.12 & 90.3 & 180.42 & 1243.74 & 344.82 & 1588.56 \\
\hline $\mathbf{T}_{\mathbf{4}}$ & 39.56 & 71.57 & 111.13 & 19.55 & 20.85 & 40.4 & 79.12 & 82.61 & 161.73 & 1084.58 & 285.48 & 1370.06 \\
\hline $\mathbf{T}_{\mathbf{5}}$ & 40.96 & 74.98 & 115.94 & 22.75 & 23.85 & 46.6 & 84.65 & 86.83 & 171.48 & 1166.09 & 312.29 & 1478.38 \\
\hline $\mathbf{S E m} \pm$ & 0.510 & 0.578 & 0.491 & 0.393 & 0.490 & 0.531 & 0.374 & 0.448 & .521 & 0.489 & 0.279 & 0.768 \\
\hline $\begin{array}{c}\mathbf{C D} \\
(\mathbf{P = 0 . 0 5})\end{array}$ & 1.608 & 1.823 & 1.567 & 1.238 & 1.545 & 1.752 & 1.180 & 1.411 & 1.791 & 1.543 & 0.880 & 2.423 \\
\hline
\end{tabular}




\section{REFERENCES}

Abdel-Motagallya F.M.F. and El-zohari M., 2016. Improvement of wheat yield grown under drought stress by boron foliar application at different growth stages. J. Saudi Soc. Ag. Sci., 17: 178-185.

Ahmed S., 2001. Effect of boron and zinc application on dry matter yield and nutrient uptake of wheat. In: Proc. of the International Workshop on Boron, University Bonn, Germany: 2328.

Berger K.C. and Troug E., 1939. Boron determination in soils and plants. Indian Engineering Analysis Education, 11: 540-545.

Canada A.L., 2002. Boron as a Plant Nutrient. A \& L Canada Laboratories, Jetstream Rd., London, 3:519-457.

Chander G. Verma T.S. and Sharma S., 2010. Nutrient content of cauliflower (Brassica oleracea L. var. botrytis) as Influenced by boron and farmyard manure in north west Himalayan Alfisols. J. Indian Soc. Soil Sci., 58: 248-251.

Chapman H.D. and Pratt P.F., 1961. Methods of Analysis for Soil, Plants and Water. University of California, Berkeley, CA, USA.

Cheng C. and Rerkasem B., 1993. Effects of boron on pollen viability in wheat. Plant nutrition from genetic engineering to field practice. Dordrecht: Kluwer Academic Publishers, pp.405-407.

Dell B. and Huang L.B., 1997. Physiological response of plants to low boron. Pl. Soil. 193: 103-120.

El-Dissoky R.A. and Abdel-Kadar A.E.S., 2013. Effect of boron as a foliar application on some potatoes cultivars under Egyptian alluvial soils conditions. Res. J. Ag. Bio. Sci., 9: 232-240.

Hossain M.A. Jahiruddin M. and Khatun F., 2011. Effect of boron on yield and mineral nutrition of mustard (Brassica juncea L.). Bangladesh J. Ag. Sci., 36: 67-73.

Jackson M.L., 1973. Soil Chemical Analysis, Prentice Hall of India. Pvt. Ltd. New Delhi.

Jaiswal A.D., Singh S.K., Singh Y.K., Singh S. and Yadav N.S., 2015. Effect of sulphur and boron on yield and quality of mustard (Brassica juncea L.) grown on Vindhyan red soil. J. Indian Soc. Soil Sci., 63: 362-364.

John M.K., Chuah H.H. and Neufied J.H., 1975. Application of improved azomethine- $\mathrm{H}$ method to the determination of boron in soils and plants. Analy. Lett., 8: 559-568.

Kar S. and Motirmani D.P., 1976. Potassium boron relationships in plant nutrition. Bull. Indian Soc. Soil Sci., 10: 99-102.

Mubshar H., Ayaz K.M., Bismillah K.M., Mohammad F. and Sahid F., 2012. Boron application improves growth, yield and net economic return of rice. China National Rice Res. Ins. Pub. Els. Rice Sci., 3: $259-262$.

Olsen S.R., Cale C.V., Watanble F.S. and Dean L.A., 1954. Estimation of available phosphorus is soil by extraction with sodium bicarbonate. United States Department Agriculture Circular, 939: 19-23.

Rehman S.U., Hussain N., Tariq M., Hussain M., Nasir M. and Ayaz M., 2012. Response of wheat to exogenous boron supply at various growth stages. Sharad J. Agric., 28: 411-414.

Rehman A., Farooq M., Ata cheema Z., Nawaz A. and Wahid A., 2014. Foliage applied boron improves the panicle fertility, yield and biofortification of fine grain aromatic rice. J. Soil Sci. Pl. Nutr., 14:723-733.

Rerkasem B. and Jamjod S., 2004. Boron deficiency in wheat a review. Field Crop Res., 89: 173-186.

Sentimenla, Singh A.K. and Singh S., 2012. Response of soyabean to phosphorus and boron fertilization in acidic upland soil of Naga Land. J. Indian Soc. Soil Sci., 60: 167-170.

Singh M.V. and Goswami V., 2014. Boron management in Indian agriculture. Indian J. Fert., 10: 104-115.

Singh P.S. and Nayar V.K., 2000. Available boron status of some alluvium derived arid and semi arid soils of Punjab. J. Indian Soc. Soil Sci., 47: 801-802. 


\section{PATEL ET. AL.: EFFECT OF FOLIAR APPLICATION OF BORON AT DIFFERENT STAGES OF CROP...}

Soomro Z.H., Baloch P.A. and Gandhai A.W., 2011. Comparative effects of foliar and soil applied boron on growth and fodder yield of maize. Pak. J. Ag., Agricultural Eng. Veterinary Sci., 27:18-26.

Subbiah B.V. and Asija G.L., 1956. A rapid procedure for the determination of available nitrogen in soils. Curr. Sci., 25: 259-260.

Tariq M.A., Akbar L. Haq and Amanullah, 2010. Comparing application methods of boron fertilizer for the yield and quality of tobacco (Nicotiana tabacum L.). Congress of Soil Sciience, Faisalabad, Pakistan: pp.22-27.

Walkley A. and Black I.A., 1934. An examination of the Degtjareff methods for determining soil organic matter and proposed modifications of the chromic acid titration method. Soil Sci., 37: 29-38. 